\title{
INTERNATIONALIZATION OF SMES: BETWEEN GLOBAL VALUE CHAINS AND E-COMMERCE
}

\author{
Mohammed Sqalli Houssaini \\ ENCG, Moulay Ismaïl University, Morocco \\ E-mail: Sqalli.hm@gmail.com \\ Jean Jeaslin Decossa \\ ENCG, Ibn Tofail University, Morocco \\ Aya Slaoui \\ ENCG, Moulay Ismaïl University, Morocco
}

\begin{abstract}
Throughout the lines of this article, we tend to expose the different theoretical approaches to the internationalization of Small and Medium-Sized Enterprises (SMEs). In particular, this paper aims to present the main approaches proposed not only in the literature but also in the shadow of the new international behaviors of SMEs, to question their scope. Moreover, this contribution seeks to draw attention to new types of internationalization among SMEs, in this case, participation in Global Value Chains $(G V C s)$ and electronic commerce (e-commerce).
\end{abstract}

Keywords: Internationalization, SMEs, Theoretical approaches, Global Value Chains, Ecommerce.

\section{INTRODUCTION}

The role of Small and Medium Enterprises (SMEs) is crucial in the economic development of any country (Wang, 2016). These entities represent the core of the business base around the world (Abdin, 2017). The study of their specificities and the analysis of their behavior is important for the advancement of research in management science (Chabaud \& Sammut, 2016).

With globalization and the emergence of new forms of trade, SMEs are confronted with local and international competitions (WTO, 2016). On that point, the tools and strategies to be implemented to guarantee themselves sustainability in the market can relate to actions on a national scale, also, on a global scale, by internationalizing (Paul et al., 2017).

The internationalization of SMEs has been an area of interest for researchers for several decades (Kazlauskaité, 2015; Hsieh et al., 2019). The development of these companies beyond their national borders has given rise to different theoretical approaches, each attempting to emphasize a particular aspect: approach by stages (Johanson \& Vahlne, 1977; 2009), by networks (Johanson \& Vahlne, 1990; Musteen et al., 2014), through resources and skills (Laghzaoui, 2009), the "Born-Global" approach (Oviatt \& McDougall, 1994; Knight \& Cavusgil, 2004; 2005; Servantie, 
2007; Cabrol \& Favre-bonté, 2011; Elidrissi et al., 2017) and the economic approach (Dunning, 1988; Brouthers \& Nakos, 2002; 2004), etc.

In regards to the plurality of internationalization approaches of SMEs, it turns out to be necessary to call upon a unifying framework that takes into account two main elements; on the one hand, the different theoretical components, and on the other hand, new trends in the behavior of SMEs abroad.

This article aims to solve an issue which can be stated as the following question: to what extent do the different approaches existing in the literature make it possible to grasp the new trends characterizing the launch of SMEs internationally?

This paper is organized as follows: first, we deal with SMEs by listing their quantitative and qualitative specificities. Second, we are revisiting the internationalization approaches of SMEs. Then, we focus on two new forms of internationalization among SMEs, namely integration into Global Value Chains (GVCs) and electronic commerce (e-commerce). To this end, we question the adaptability of the theoretical approaches available in these new behaviors. Finally, we list a set of research avenues.

\section{SMEs BETWEEN QUANTITATIVE CATEGORIZATION AND QUALITATIVE SPECIFICITIES}

The plurality of SMEs across economies means that there is no standard definition of the concept. Indeed, the expression "SMEs" in the plural would be more appropriate to study this type of business (Torrès, 2003). With this regard, we consider in this work the quantitative and qualitative specificities of these entities to better comprehend the concept.

\section{Quantitative specificities of SMEs}

A triggering inquiry related to the SME's analysis comes up and it consists in asking whether the lessons learned from studies on large companies, models, and theories can be applied to SMEs (Curran and Blackburn, 2001; Torrès \& Julien, 2005). On that point, the managerial literature agrees that SMEs have their specificities (Aylin et al. 2013; Blackburn et al. 2013; Chabaud \& Sammut, 2016; Dominguez \& Mayrhofer, 2016) and the fact of trying to copy the strategies and management methods of large entities on SMEs would be a mistake (Brouthers \& Nakos 2005; Eliot et al. 2009).

Throughout the literature, measurement to evaluate these companies is often quantitative and fits into a logic of size. Nonetheless, size is not necessarily a sufficient criterion to categorize this type of entity (Torrès \& Julien, 2005). Depending on the country in question, the acronym "SME" does not specifically refer to an upper or lower size limit (Criscuolo et al. 2014).

In this perspective, if SMEs are globally unified company names (Gibson and Van der Vaart, 2008), their quantitative measurement varies from one economy to another (Forsman 2008; Ayyagari et al., 2011). For instance, the European Union specifies the measurement of SMEs by 
job thresholds and turnover; between 10 and 50 employees and a turnover of fewer than 10 million euros for small businesses, and between 50 to 250 employees with a turnover limited to 43 million euros for medium ones (European Commission, 2013). In the United States, a company with 500 employees is considered to be of medium size (North American Industry Classification System, 2012). In China, size categorization varies by industry (National Bureau of Statistics of China, 2011). In Morocco, the workforce is not specified and the turnover for the medium-sized enterprise is limited to 175 million dirhams (Ministry of Economy and Finance, 2013).

Moreover, the quantitative measure alone does not allow a complete framing of SMEs. This leads us to discuss their qualitative specificities (Chabaud \& Sammut, 2016), and to emphasize the constraints which they confront (Lee et al., 2010; Barlette, 2011; Wang, 2016).

\section{Qualitative characteristics of SMEs}

Regardless of the sector of activity, certain characteristics are specific to SMEs, namely: flexibility, entrepreneurial orientation (Aloulou and Fayolle, 2005), short-term vision (HudsonSmith and Smith, 2007; Aylin \& al, 2013), tacit knowledge (Darby \& Zucker, 2003; Pillania, 2008) and the preponderance of the role of the manager-entrepreneur (Chabaud, 2013; Jaouen \& Lasch, 2015; Chabaud \& Sammut, 2016; Dominguez \& Mayrhofer, 2016).

By emphasizing the differences between SMEs managed by owner-manager-founders and SMEs managed by professional-committed managers, the empirical results of the first works by Filion (1996) to the recent study by Deb and Wiklund (2017), demonstrate that entrepreneurial management tends to encourage engagement, the search for opportunities, good corporate governance, and organizational learning.

Additionally, if the manager favors the reactivity of his business, the level of strategic planning remains quite low and often not formalized (Hudson-Smith and Smith, 2007), which characterizes the SME by a logic of short-term priority (Aylin et al, 2013). However, this lack of strategic structuring allows the SME to respond to the opportunities that arise by tolerating a certain degree of risk-taking (Aloulou \& Fayolle, 2005).

In general, SMEs adopt less formalized systems in terms of management and decision-making compared to large companies. However, the absence of structured management generates difficulties in knowledge transfer (Aylin et al., 2013). This points us to another characteristic of small and medium-sized enterprises, namely tacit knowledge.

Within SMEs, knowledge is mainly created by the accumulation of experiences and is absorbed through tacit learning which results in non-explicit knowledge (Ward, 2004). However, the transition from tacit knowledge to explicit knowledge is not without difficulties (Darby \& Zucker, 2003).

Indeed, the engagement in new activities, the management model of the SME, and decisionmaking in general (Dominguez \& Mayrhofer, 2016) are elements linked mainly to the manager 
who constitutes the central figure of his company (Chabaud, 2013; Jaouen \& Lasch, 2015; Chabaud \& Sammut, 2016), to the point that the personal reputation of the SME manager is directly linked to that of his entity while being a source of value (Torrès, 2011).

This manager, who is the cornerstone of his business, is characterized by a set of specificities influencing the management style and strategic orientation of his SME (Deb and Wiklund, 2017). This is the case with his previous experiences, even with his psychological characteristics (Richbell et al., 2006; Grandclaude \& Nobre, 2013; Islam, \& Barghouthi, 2018a).

Through empirical studies, and starting from the research of Storey (1994) to the work of Blackburn et al., (2013); it appears that certain backgrounds of the manager have an impact on the growth and performance of SMEs (Blackburn et al., 2013): The Age of the manager (Dobbs and Hamilton, 2007), his experience (Delmar \& Wiklund, 2008), his training (Barringer \& Jones, 2004), his entrepreneurial history (Barringer et al., 2005), his previous functions (Richbell et al., 2006), the previous sector of activity (Storey, 1994), the size of the previous entity (Richbell et al., 2006), etc.

In short, it should be noted that, on the one hand, SMEs are companies with their characteristics and where the manager occupies a major place. On the other hand, these companies still face a set of constraints that hinder their development and growth (Wang, 2016; Woschke et al., 2017): managerial constraints (Fuller-Love, 2006; Islam, \& Barghouthi, 2018b; Hudson-Smith and Smith, 2007; Aylin et al. 2013), information constraints (Chtourou, 2006; Moinet and Philippe, 2007; Barlette, 2011) and financial constraints (Lee et al., 2010; Torrès, 2011).

Within SMEs, the manager occupies different positions at the same time, performing managerial and operational level tasks, the latter often occupy a good part of the manager's time (Aylin et al., 2013). In this regard, managerial practices are closely linked to the individual skills of the entrepreneur, and developing the skills of the manager or the management team is a way of developing the organizational capabilities of SMEs (Fuller-Love, 2006).

This limitation of resources also applies to the financial aspect; financial constraints are widely studied in the literature, supporting the idea that the size of SMEs hinders access to finance (Lee et al., 2010; Wang, 2016).

In general, the specificities of SMEs, their constraints, and the obstacles they encounter mean that these entities are looking for means to develop further to ensure their survival but also to ensure themselves new sources of income. To this end, SMEs can opt for development beyond their national borders, by internationalizing.

\section{INTERNATIONALIZATION OF SMES}

Internationalization is seen as a lever for business development, offering them the possibility of having several sources of income both on a national and international level (WTO, 2016). 


\section{Internationalization}

The concept of "internationalization" is used to describe the geographic expansion of the company's economic activities beyond its national borders, grouping the different modes of international market entry: Direct exports, indirect exports, subcontracting, Foreign Direct Investments (Zeng et al., 2008; Laghzaoui, 2011; Dutot et al., 2014).

Through the literature, several researchers have tried to assign a precise definition to 'internationalization'. This implies that the definition of the concept varies depending on the phenomenon observed (Paul et al., 2017). The internationalization process leads to a wide range of decisions to be taken (Santos-Alvarez \& García-Merino, 2010) while mobilizing human and organizational resources to venture into international markets (Spowart \& Wickramasekera, 2012).

In this respect, the decision to internationalize represents a strategic choice for the firm, it allows it to ensure its survival (Filatotchev \& Piesse, 2009; Sui and Baum, 2014) and to improve its productivity (Love et al., 2016). However, internationalization leads to a confrontation with different environments, different cultures, and a multitude of institutional standards. This results in a set of obstacles, especially for small-sized businesses like SMEs.

The internationalization of SMEs is a field of research in perpetual development and which arouses the interest of a good number of researchers (Ruzzier et al., 2006; Laghzaoui, 2011; Kazlauskaité, 2015; Paul et al., 2017; Sqalli, 2020). Indeed, the first works of Bilkey (1978), as well as those of Aaby \& Slater (1989), demonstrated that, regardless of the type of internationalization of an SME, the latter will be beneficial to it. Besides, the literature relating to the field remains fragmented and no theoretical framework alone can identify the internationalization of SMEs (Crick \& Spence, 2005). This is partly explained by the multitude of international development modes, but also by the heterogeneity of SMEs around the world (WTO, 2016).

\section{Approaches to the internationalization of SMEs}

A distinction between the different approaches is established in this work through a grouping into the following categories: gradual and incremental approaches, the economic approach, the approach of rapid and accelerated internationalization, and finally the resource-based and skills approach.

\section{Stages approach}

This approach considers the concept of internationalization as a process by which the company engages in international operations gradually, to acquire more experience, by starting with lowcommitment international development methods towards markets with a reduced psychological distance and then moving on to larger operations (Johanson \& Vahlne in 1977). In this respect, the specificities of SMEs mean that such entities opt preferably for low-cost commitments, in 
particular export operations in its two forms: direct and indirect sales (Lages and Montgomery, 2005; Ragland et al., 2015).

In this regard, the literature approves that export constitutes the first stage of internationalization among SMEs. Hence, if the first export operations are successful, SMEs are increasingly involved internationally (Brouthers et al., 2009).

This approach targets a certain minimization of risks and allows the company to accumulate knowledge relating to international activities, thereby increasing its chances of survival on foreign markets (Figueira-de-lemos et al., 2011), while identifying the new opportunities (Johanson \& Vahlne, 2009).

The Uppsala model is also characterized by cultural, economic, and geographic proximity, insofar as the company first targets countries with these specificities and then begins operations towards more distant countries (Johanson \& Vahlne in 1977).

\section{Network approach}

The authors of the network approach (Johanson \& Vahlne, 1990; 2009; Coviello, 2006; Mitgwe, 2006; Musteen et al., 2014) postulate that SMEs mainly rely on their networks when they decide to internationalize.

Being considered as an extension of the stages approach (Laghzaoui, 2011), Johanson and Vahlne (2009) put forward the idea that the company evolves in an environment characterized by several relationships with other firms thus constituting its network and facilitating its international development.

Indeed, the network approach consists of optimizing the use of the information and knowledge acquired over time while involving the various partners through the establishment of close relationships with customers, suppliers, distributors, and public authorities. (Paul et al., 2017).

\section{Economic approach: Dunning's eclectic paradigm and transaction cost theory}

In addition to the reputedly incremental approaches of the internationalization of SMEs, namely gradual approaches (Stages and networks), there is a multitude of other forms of interpretation of this concept, we will cite among others the eclectic paradigm of Dunning (1988) and the theory of transaction costs, both, within the framework of the so-called "economic approaches".

Dunning's eclectic paradigm (OLI) explains internationalization through three assets: "Ownership advantages", "Localization advantages" and "internalization advantages". These three advantages are linked respectively to cumulative intangible resources factors, geographic location, and internal organizational capabilities (Laghzaoui, 2009).

Initially, this paradigm focused on large companies, later, and through the empirical results of Nakos \& Brouthers (2002), it turned out to be suitable for the study of the concept of internationalization of SMEs and mainly for the selection of the international entry mode. 


\section{Fast and accelerated internationalization approach}

The "Born-global" (Knight \& Cavusgil, 2004; 2005) or "International New venture" (Oviatt and McDougall, 1994) approach, also known in the French-speaking literature "ENI": Newly International Companies, or "EIRP": Enterprises with Rapid and Early Internationalization (Servantie, 2007; Cabrol \& Favre-bonté, 2011) is a theory of internationalization which is in the opposite direction to progressive approaches by stages or networks. It emerged in the 1990s through a study of Australian exporting companies (Rennie, 1993), the majority of which became international after a short period following their founding. The concept of new international companies continues to be the subject of much research and to interest more researchers in international entrepreneurship (Servantie et al., 2016). However, the absence of a unified denomination persists (Elidrissi et al., 2017).

The authors of this approach defend the idea that some companies develop internationally soon after their creation while earning a significant part of their income on international markets (Knight \& Cavusgil, 2005).

Empirical results have also shown that "Born-global" is more innovative than other companies (Knight \& Cavusgil, 2004). To this end, early internationalization can be triggered by technological capacities, managerial and in particular interpersonal skills (Elidrissi et al., 2017), as well as by the entrepreneur's prior network and collaborations in general (Knight \& Liesch, 2015; Paul et al., 2017). Furthermore, it is also argued in the literature that rapidly internationalizing companies are characterized by the lowest international survival rate compared to companies that have developed gradually (Sui \& Baum, 2014).

\section{Resources and skills approach}

Offering proofreading around the concept of resources and skills among the approaches to the internationalization of SMEs, the work of Laghzaoui, $(2009 ; 2011)$ lead to the observation that the grouping of the different theoretical approaches allows good assimilation of the phenomenon.

The integration of the concept of resources and skills in the internationalization of SMEs finds its foundation in the specificities of SMEs, namely: its manager, the entity itself, and its environment. These resources and skills and their combination occur upstream (triggering exports or slowing them down) and downstream (international engagement or abandonment) of the internationalization process (Laghzaoui, 2011).

In this perspective, the work of Elidrissi and his colleagues (2017) analyze the role of relational skills (individual, collective, organizational and inter-organizational) in the consolidation of international networks in 'Enterprises with Rapid and Early Internationalization'. Their results support the idea that skills within SMEs provide a good framework for analyzing the concept of internationalization (Ruzzier et al., 2007; Laghzaoui, 2009). 


\section{Putting approaches into perspective: Between electronic commerce and global value chains}

SMEs can consider other forms of internationalization that require fewer resources and involve fewer risks. In this regard, integration into Global Value Chains (GVCs) represents a good option to overcome the difficulties of access to markets located beyond national borders (Del Prete \& Rungi, 2015; WTO, 2016). Moreover, and taking into account technological advances, electronic commerce (or e-commerce) allows SMEs to have a more global vision on the markets, to access a set of information, and to reach the maximum possible market. at a lower cost (Lendle \& Olarreaga, 2017).

\section{International development of SMEs and e-commerce}

The use of new information and communication technologies (NICT) has revolutionized various aspects linked to the organizational world. This is particularly the case for information sharing, the establishment of collaborations, and the rise of new distribution channels.

The NICs have not only facilitated trade practices at the local level but also the international level. More specifically, the Internet has made it easier for businesses to gain visibility abroad and access more business opportunities at a lower cost (Pezderka \& Sinkovics, 2011; Islam, 2017).

Commerce via the internet or electronic commerce, commonly known as e-commerce, includes all transactions of goods or services performed remotely via computer networks. E-commerce revolves mainly around three axes, namely; sharing information, establishing business partnerships, and conducting trade.

The literature which is dealing with electronic commerce agrees that it constitutes a new tool for international development insofar as it allows companies to offer their products or services to consumers worldwide regardless of time or distance (Pezderka \& Sinkovics, 2011).

Indeed, as soon as a company has a website, and without necessarily aiming to develop abroad, it becomes visible to other players on the world market, and can therefore receive unsolicited orders from it. It is through this logic some authors consider e-commerce as a new model of international market entry (Bruneel et al. 2016).

More recently, studies which analyze the participation of SMEs in electronic commerce have led to a set of findings in the opposite direction to the traditional scenario of approaches regarding the internationalization of SMEs (Lendle et al. 2016): low costs of access to information, less physical distance, the gain of foreign customers' confidence, etc.

Another revealing observation, smaller companies are more present online than their larger competitors, and the former tend to benefit from the advantages of e-commerce much more than the latter. This is explained by the flexible and reactive nature of SMEs, and by the fact that large companies pursue more structured approaches in terms of internationalization while being less handicapped by international constraints (Lendle \& Olarreaga, 2017). 
Following this logic, exporting SMEs are often confronted by a series of obstacles that hinder their success and threaten their survival (Wang, 2016).

Based on the references that study those brakes (Pietrobelli \& Rabellotti, 2011; Lakew \& Chiloane-Toska, 2015), we can distinguish the following categories: difficulties of access to finance, lack of information and intelligence relating to foreign markets and in international operations, insufficient human skills, high costs of certain services, currency risks and currency fluctuations.

To overcome these barriers, SMEs can consider other forms of internationalization requiring fewer resources and entailing less risk. In this regard, Global Value Chains (GVCs) are a good option to overcome these difficulties in accessing markets beyond national borders (WTO, 2016).

\section{Internationalization by global value chains}

GVCs encompasses a set of activities - from design to distribution - constituting a production process aimed at providing a good to the end consumer (Cattaneo et al., 2010; Baldwin and Vanables, 2013). The components of the good are produced and assembled in different countries and the operation is part of a vertical fragmentation production logic (Del Prete \& Rungi, 2015).

SME participation in GVCs can be done in two ways, either by exporting directly to a country that is also part of a production and distribution chain or by exporting indirectly through the sale of the products of the SME by a larger exporting company.

In this regard, the integration of SMEs in GVCs can be beneficial in several areas, explicitly for the transfer of information and knowledge (Piermartini \& Rubínová, 2014), the gain in productivity (Newman et al, 2015), and building a reputation as a supplier to large companies (Sutton, 2012; Islam, \& Karim Miajee, 2018b).

Furthermore, and according to the 2016 WTO report, there are just a few scientific works analyzing indirect exports from SMEs through GVCs. In a similar vein, the recent results of Del Prete and his colleagues (2017) advance the idea that encouraging the participation of SMEs in GVCs has a positive impact on the industry and the level of development in the country. This constitutes a challenge for the countries of North Africa since this geographic area remains less engaged in GVCs.

\section{Theoretical approaches: Limited scope and need for a global framework}

The emergence of the participation of SMEs in GVCs is indicative of an essential point: the classic internationalization approaches existing in the literature do not provide a transversal reading grid. Indeed, each approach interprets the behavior of SMEs internationally through a restrictive vision of the concept; if some authors base themselves on explanatory cost variables (Dunning, 1988; Brouthers \& Nakos, 2002; Islam, Hossain, Zaman, \& Miajee, 2013), others opt for a gradual logic over time (Johanson \& Vahlne, 1977; 1990; 2009; Coviello, 2006; Mitgwe, 
2006; Musteen et al., 2014) or at the opposite, refer to an accelerated rhythm (Oviatt \& McDougall, 1994; Knight \& Cavusgil, 2004; 2005).

Along these same lines, we can say that certainly each approach is useful for understanding the behavior of SMEs internationally, but only in a specific context. This indeed leads us to question the need for a global framework that takes into account the new trends influencing the internationalization of SMEs, in this instance, GVCs and e-commerce.

In a certain perspective, if the network approach refers to the establishment of collaboration with foreign partners, (Johanson \& Vahlne, 2009), indirect internationalization by global value chains can be done through collaborations at the local level (Del Prete \& Rungi, 2015). From another perspective, internationalization by stages considers that engagement in foreign markets is done gradually based on two factors: psychic distance and organizational learning. In e-commerce, in contrast, recent publications have concluded that cultural, procedural, and economic distances act differently on the decision of SMEs to venture abroad (Lendle et al., 2016). Lastly, accelerated internationalization is mainly initiated by technological capacities, the manager's network, or even the manager's international experience (Islam, \& Miajee, 2018a; Servantie, 2007; Cabrol and Favre-bonté, 2011; Servantie et al., 2016). To this end, new trends are still not identified through scientific publications as an accelerator to international development among small businesses.

\section{CONCLUSION}

In the light of what has been discussed; this article attempts to revisit the main theoretical approaches relating to international development among SMEs. This article also sheds light on new trends characterizing the behavior of SMEs conducting transactions with partners abroad. Indeed, these elements refer to the need to develop a reflection allowing us to arrive at a more global framework.

The participation of SMEs in international trade through GVCs and electronic commerce represent new areas of research to be developed to better understand these phenomena. Therefore, a future line of research can be proposed:

On the one hand, competition within GVCs is increased since integration into channels is done based on the logic of lower costs (Abonyi, 2005). On that point, it would be wise to focus on the factors fostering the survival of SMEs in GVCs, as well as, on the skills contributing to the start of indirect exports.

On the other hand, the transfer of information and knowledge within the framework of established collaborations, the role and network of the manager as well as the transition from indirect exports to direct exports within GVCs are all fields of study to explore and which can be beneficial, especially in regions that still have a long way to go in terms of integrating their SMEs into Global Value Chains (Del Prete et al., 2017). 
Regarding e-commerce, it would be relevant to emphasize the role of virtual commerce platforms as sources of information and their impact on the distances traveled by SMEs through export operations or their influence on triggering these activities.

However, this paper may be subject to some research limitations, particularly in terms of the theoretical framing of the different approaches to the internationalization of SMEs. Indeed, there are other approaches for analyzing the concept; moreover, no theory alone allows us to define the phenomenon (Crick \& Spence, 2005; Paul et al., 2017).

\section{REFERENCES}

Aaby, N. E., \& Slater, S. F. (1989). "Management influences on export performance: a review of the empirical literature 1978-1988". International marketing review, 6(4).

Abdin, Md. (2017). Joynal, SMEs and Our Development Goals (February 25, 2017).

Abonyi, G. (2005), "Transformation of Global Production, Trade and Investment: Global Value Chains and International Production Networks", Expert Group Meeting on SMEs Participation in Global and Regional Supply Chains, CESAP, Bangkok.

Aloulou, W. and Fayolle, A. (2005), "A conceptual approach of entrepreneurial orientation within small business context", Journal of Enterprising Culture, Vol. 13 No. 1, pp. 2145.

Aylin AtesPatriziaGarengo Paola CoccaUmitBititci, (2013), "The development of SME managerial practice for effective performance management", Journal of Small Business and Enterprise Development, Vol. 20 Iss 1 pp. 28 - 54

Ayyagari, M., Demirgüc-Kunt, A. et Maksimovic, V. (2011), "Small vs. Young Firms across the World", document de travail n 5631, Banque mondiale, Washington DC.

Baldwin, R. and Venables, A. J. (2013). "Spiders and snakes: Offshoring and agglomeration in the global economy". Journal of International Economics, 90(2):245-254.

Barringer, B.R. and Jones, F.F. (2004), "Achieving rapid growth - revisiting the managerial capacity problem", Journal of Developmental Entrepreneurship, Vol. 9 No. 1, pp. 73-87.

Barringer, B., Jones, F., Foard, F. and Neubaum, D. (2005), "A quantitative content analysis of the characteristics of rapid growth firms and their founders", Journal of Business Venturing, Vol. 20 No. 5, pp. 663-87.

Barlette, Y., (2011), "Implication, action des dirigeants de PME et niveau de sécurité de leur S.I." Systèmesd'Information et Management 17(2):115-149.

Bilkey, W. J. (1978). "An attempted integration of the literature on the export behavior of firms". Journal of international Business studies, 33-46.

Brouthers, K.D. \& Nakos, G. (2004), "SME Entry Mode Choice and Performance: A Transaction Cost Perspective". Entrepreneurship Theory and Practice, Vol. 28, $\mathrm{n}^{\circ} 3$, p.229-247.

Brouthers, L. E., Nakos, G., Hadjimarcou, J., \& Brouthers, K. D. (2009). "Key factors for successful export performance for small firms". Journal of International Marketing, 17(3), 21-38.

Brouthers, L. E. et Nakos, G. (2005), "The role of systematic international market selection on small firms' export performance”, Journal of Small Business Management 43(4): 363381. 
Cattaneo, O., Gereffi, G., and Staritz, C. (2010). "Global value chains in a postcrisis world: a development perspective". World Bank Publications.

Chabaud, D., Degeorge, J.-M. (2013), "Les dirigeants aujourd'hui, in D. Chabaud (dir.), Qui sont vraiment les dirigeants des PME ?" (pp. 21-39), Paris, EMS.

Charles B. Ragland, Lance Eliot Brouthers, Scott M. Widmier, (2015) "Institutional theory and international market selection for direct selling”, Marketing Intelligence \& Planning, Vol. 33 Issue: 4, pp.538-555, doi: 10.1108/MIP-02-2014-0033

Crick, D. and Spence, M. (2005). "The internationalisation of 'high performing' UK high-tech SMEs: a study of planned and unplanned strategies", International Business Review, 14/2, 167-185.

Criscuolo, C., Gal, P. N. et Menon, C. (2014), "The dynamics of employmentgrowth: new evidencefrom 18 countries", document de travail $n^{\circ} 14$, Organisation de coopération et de développement économiques, Paris.

Commission européenne (2013) "A Recovery on the Horizon? Annual Report on European SMEs", Bruxelles: Commission européenne.

Coviello, N.E. (2006), "The network dynamics of international new ventures", Journal of International Business Studies, vol. 37, $\mathrm{n}^{\circ}$ 5, p. 713-731.

Darby, M. and Zucker, L. (2003), "Metamorphic learning”, Economic Inquiry, Vol. 41, pp. 119.

Davide Del Prete, GiorgiaGiovannetti and Enrico Marvasi, (2017) "Global Value Chains: new evidence for North Africa, International Economics”, http://dx.doi.org/10.1016/j.inteco.2017.03.002

Deb, P., \& Wiklund, J. (2017). "The Effects of CEO Founder Status and Stock Ownership on Entrepreneurial Orientation in Small Firms". Journal of Small Business Management, 55(1), 32-55.

Del Prete, D. and Rungi, A. (2015a). "Organizing the Global Value Chain: a firm-level test". EIC working paper series \#4/2015 IMT Institute for Advanced Studies Lucca ISSN 2279-6894.

Didier Chabaud, Sylvie Sammut, "Le dirigeant au cœur des dynamiques entrepreneuriales des PME”, Revue de l'Entrepreneuriat 2016/1 (Vol. 15), p. 7-13. DOI 10.3917/entre.151.0007.

Didier Grandclaude, Thierry Nobre, (2013), "Caractéristiques du propriétaire dirigeant de PME, entre l'être et le faire, où en sommes-nous ?" XXIIèmeconférence de l'AIMS, At Clermont-ferrand.

Dobbs, M. and Hamilton, R. (2007), "Small business growth: recent evidence and new directions", International Journal of Entrepreneurial Behaviour\& Research, Vol. 12 No. 5, pp. 296-322.

Dominguez, N., Mayrhofer, U. (2016), "Il n'est jamais trop tard pour entreprendre" : l'internationalisation des born-again globals", Revue de l'entrepreneuriat, vol. $15, \mathrm{n}^{\circ} 1$.

Dunning, J. H. (1988). "The eclectic paradigm of international production: A restatement and some possible extensions". Journal of international business studies, 1-31.

Dutot, V., Bergeron, F., \& Raymond, L. (2014). "Information management for the internationalization of SMEs: An exploratory study based on a strategic alignment perspective". International Journal of Information Management, 34(5), 672-681. 
Elidrissi, D., Hauch, V., \&Loufrani-Fedida, S. (2017), "La dynamique des compétences relationnelles dans le développement des entreprises à internationalisation rapide et précoce : une approche multi-niveaux", Revue internationale PME - Vol. 30 - 2017 (n¹)

Forsman, H. (2008), "Business development success in SMEs: a case study approach", Journal of Small Business and Enterprise Development, Vol. 15 No. 3, pp. 606-22.

Figueira-de-Lemos, F., Johanson, J., \& Vahlne, J. E. (2011). "Risk management in the internationalization process of the firm: A note on the Uppsala model". Journal of World Business, 46(2), 143-153.

Fuller-Love, N. (2006), "Management development in small firms", International Journal of Management Reviews, Vol. 8 No. 3, pp. 175-90.

Filion, L. (1996), "Differences in managerial systems of owner-managers - small-business entrepreneurs and small-business operators", Canadian Journal of Administrative Sciences - Revue Canadienne des Sciences de l'Administration, Vol. 13, pp. 306-20.

Gibson, T. et van der Vaart, H. J. (2008), "Defining SMEs: A Less Imperfect Way of Defining Small and Medium Enterprises in Developing Countries", Brookings Global Economy and Development, Washington DC

Hudson-Smith, M. and Smith, D. (2007), "Implementing strategically aligned performance measurement in small firms", International Journal of Production Economics, Vol. 106 No. 2, pp. 393-408.

Hsieh, L., Child, J., Narooz, R., Elbanna, S., Karmowska, J., Marinova, S., ... \& Zhang, Y. (2019). "A multidimensional perspective of SME internationalization speed: The influence of entrepreneurial characteristics". International Business Review, 28(2), 268283.

Islam, K. A., Hossain, S. A., Zaman, M., \& Miajee, M. R. K. (2013). Poverty Alleviation in Bangladesh through Small and Medium Enterprise (SME) Loan: A Case Study on United Commercial Bank Limited at Gulshan Branch. Bangladesh Research Foundation Journal, 2(3),29-43.

Islam, K. M. A. (2017). Predicament and Thought of SMEs Financing in Bangladesh: An Exploratory Research. Indian journal of arts,7(22), 146-151.Retrieved from https://discoveryjournals.org/arts/current_issue/2017/A17.pdf

Islam, K. A., \& Miajee, M. R. K. (2018a). Small and Medium Enterprises (SMEs) Financing in Bangladesh: A Review of Literature. International Journal of Small and Medium Enterprises, 1(1), 11-15. https://doi.org/10.46281/ijsmes.v1i1.62

Islam, K. M. A., \& Karim Miajee, M. R. (2018b). Exploring E-Business in SMEs. International Journal of Small and Medium Enterprises, 1(1), 16-18. https://doi.org/10.46281/ijsmes.v1i1.63

Islam, K. M. A., \& Barghouthi, O. A. (2018a). To What Extent Do the Investment Programs in the Infrastructure Sector Comply with the Determinants of National Competitive Advantage?.International Journal of Small and Medium Enterprises, 1(1), 6-10. https://doi.org/10.46281/ijsmes.v1i1.61

Islam, K. M. A., \& Barghouthi, O. A. (2018b). To What Extent Do the Investment Programs in the Small and Medium Enterprises Sector Comply with the Determinants of National Competitive Advantage?. International Journal of Small and Medium Enterprises, 1(1), 1-5. https://doi.org/10.46281/ijsmes.v1i1.60

James Curran and Robert A. Blackburn (2001), "Researching the Small Enterprise", Sage Publications, London. Pp 192, ISBN 076195295 
J. Paul, et al., "Exporting challenges of SMEs: A review and future research agenda", Journal of World Business (2017), http://dx.doi.org/10.1016/j.jwb.2017.01.003

Jaouen, A., Lasch, F. (2015), "A new typology of micro-firm owner-managers", International Small Business Journal, vol. 33, n 4, pp. 397-421.

Johanson, J., \& Vahlne, J. E. (1992). "Management of foreign market entry". Scandinavian International Business Review, 1(3), 9-27.

Johanson, J., \& Vahlne, J. E. (1977). "The internationalization process of the firm-a model of knowledge development and increasing foreign market commitments". Journal of international business studies, 23-32.

Kazlauskaitè, R., Autio, E., Gelbūda, M., \&Šarapovas, T. (2015). "The Resource-based View and SME Internationalisation: An Emerging Economy Perspective". Entrepreneurial Business and Economics Review, 3(2), 53-64.

Knight, G.G. \& Cavusgil, S.T. (1996). "The born global firm: A challenge to traditional internationalization theory". Advances in International Marketing, 8, 11-26

Knight, G.A. and Cavusgil, S.T. (2004), "Innovation, organizational capabilities, and the bornglobal firm", Journal of International Business Studies, Vol. 35 No. 4, pp. 124-141.

Knight G., Cavusgil T. (2005), "A Taxonomy of Born-global Firms", Management International Review, $\mathrm{n}^{\circ} 45, \mathrm{p} .15-35$.

Lages, L. F. et Montgomery, D. B. (2005), "The relationship between export assistance and performance improvement in Portuguese export ventures. An empirical test of the mediating role of pricing strategy adaptation", European Journal of Marketing 39(7-8): 755-784.

Lakew, Y. D. et Chiloane-Tsoka, G. (2015), "Internationalisation Barriers of Small and Medium-sized Manufacturing Enterprises in Ethiopia: Leather and Leather Products Industry in Focus", International Journal of Business and Development 3(3): 68-80

Lance Eliot Brouthers, George Nakos, John Hadjimarcou, and Keith D. Brouthers (2009), "Key Factors for Successful Export Performance for Small Firms", Journal of International Marketing, Vol. 17, No. 3, 2009, pp. 21-38

Lendle, A., \& Olarreaga, M. (2017). "Can online markets make trade more inclusive?" (No. 742). ADBI Working Paper Series.

Lendle, A., Olarreaga, M., Schropp, S., \&Vézina, P. L. (2016). “There goes gravity: eBay and the death of distance". The Economic Journal, 126(591), 406-441.

Lee, S., Park, G., Yoon, B., and Park, J. (2010) "Open innovation in SMEs- an intermediated network model”. Research Policy, 39, 2, 290-300.)

Love, J. H., Roper, S., \& Zhou, Y. (2016). "Experience, age and exporting performance in UK SMEs". International Business Review, 25(4), 806-819.

Mathieu Cabrol, Véronique Favre-Bonté. "L'entrepreneur comme clef de voûte dans l'internationalisation rapide de son entreprise". Revue Internationale PME, Editions EMS, 2011,'’23 (2), pp.111-137.

Ministère de l'Economie et des Finances (2015). "Note de Conjoncture ", Direction des Etudes et des Prévisions Financières, Rapport Mars, N²17.

Mitgwe, B., 2006. "Theoretical Milestones in International Business: The Journey to International Entrepreneurship Theory”, Journal of International Entrepreneurship, Vol. 4, pp. 5-25. 
Mitja Ruzzier Robert D. HisrichBostjanAntoncic, (2006), "SME internationalization research: past, present, and future", Journal of Small Business and Enterprise Development, Vol. 13 Iss 4 pp. $476-497$

Musteen, M., Datta, D. K., \& Butts, M. M. (2014). "Do international networks and foreign market knowledge facilitate SME internationalization? Evidence from the Czech Republic". Entrepreneurship Theory and Practice, 38(4), 749-774.

Nakos, G. \& Brouthers K. D, (2002), "Entry Mode Choice of SMEs in Central and Eastern Europe", Entrepreneurship Theory and Practice, Vol. 27, n 1, p.47-64

Newman, C., Rand, J., Talbot, T. et Tarp, F. (2015), "Technology transfers, foreign investment and productivity spillovers", European Economic Review 76: 168-187.

Nicolas Moinet, Philippe Darantière, "Organiser la veille stratégique dans l'entreprise : conduite du changement, communautés professionnelles et stratégie- réseau", Market Management 2007/4 (Vol. 7), p. 94-109.

NiklasÅkerman, (2014) “An international learning typology: strategies and outcomes for internationalizing firms", Baltic Journal of Management, Vol. 9 Issue: 4, pp.382-402, doi: 10.1108/BJM-12-2013-0176

Olivier Torrès, "Proxémies financières des PME. Les effets collatéraux de la financiarisation des banques", Revue française de gestion 2011/4 (n²13), p. 189-204.

O. TORRES (2003), "Petitesse des entreprises et grossissement des effets de proximité", Revue Française de Gestion, $\mathrm{n}^{\circ} 144$, mai-juin 2003, p. 119-138

Oviatt, B. M., \& McDougall, P. P. (1994). "Toward a theory of international new ventures". Journal of international business studies, 45-64.

Piermartini, R. et Rubínová, S. (2014), "Knowledge spillovers through international supply chains", document de travail $n^{\circ}$ ERSD-2014-11, OMC, Genève

Pietrobelli, C. et Rabellotti, R. (2011), "Global value chains meet innovation systems: are there learning opportunities for developing countries?", World Development 39(7): 12611269.

Robert A. Blackburn Mark Hart Thomas Wainwright, (2013), "Small business performance: business, strategy and owner-manager characteristics", Journal of Small Business and Enterprise Development, Vol. 20 Iss 1 pp. 8 - 27

Pezderka, N., \& Sinkovics, R. R. (2011). "A conceptualization of e-risk perceptions and implications for small firm active online internationalization". International Business Review, 20(4), 409-422.

Pillania, R.K. (2008), "Creation and categorization of knowledge in automotive components SMEs in India”, Management Decision, Vol. 46 No. 10, pp. 1452-64.

Rennie, M. W. (1993). "Born global”. The McKinsey Quarterly, (4), 45-53.

Richbell SM, Watts HD and Wardle P (2006) "Owner-managers and business planning in the small firm”. International Small Business Journal 24(5): 496-514.

Ruzzier, M., AntonciC, B., Hisrich, R. D., \&Konecnik, M. (2007). "Human capital and SME internationalization: A structural equation modeling study". Canadian Journal of Administrative Sciences/Revue Canadienne des Sciences de l'Administration, 24(1), 1529.

Santos-Álvarez, V., \& García-Merino, T. (2010). "The role of the entrepreneur in identifying international expansion as a strategic opportunity". International Journal of Information Management, 30(6), 512-520. 
Servantie, V., Cabrol, M., Guieu, G., \&Boissin, J. P. (2016). "Is international entrepreneurship a field? A bibliometric analysis of the literature (1989-2015)". Journal of International Entrepreneurship, 14(2), 168-212.

Soulaimane Laghzaoui, "SMEs' internationalization: an analysis with the concept of resources and competencies", Journal of Innovation Economics \& Management 2011/1 (n7), p. 181-196.

Soulaimane Laghzaoui, "Internationalisation des PME : apports d'une analyse en termes de ressources et compétences", Management \& Avenir 2009/2 (n²2), p. 52-69.

Spowart, M., \& Wickramasekera, R. (2012). "Explaining internationalisation of small to medium sized enterprises within the Queensland food and beverage industry". International Journal of Business and Management, 7(6), 68-80.

Sqalli, H. M., (2020). Pratiques de sécurité informationnelle des PME exportatrices : le volet défensif de l'intelligence économique. Revue Internationale d'Intelligence Economique, R2ie, Vol. 12-1/2020.

Storey, D. J. (1994a) “Understanding The Small Business Sector”. London: Routledge.

Sutton, J. (2012), "Competing in Capabilities: The Globalization Processes", Oxford: Oxford University Press.

S.X. Zeng X.M. Xie C.M. Tam T.W. Wan, (2008), "Competitive priorities of manufacturing firms for internationalization: an empirical research", Measuring Business Excellence, Vol. 12 Iss 3 pp. 44 - 55

TinoWoschke HeikoHaase Jan Kratzer, (2017), "Resource scarcity in SMEs: effects on incremental and radical innovations", Management Research Review, Vol. 40 Iss 2 pp. -

Torrès, O., \& Julien, P. A. (2005). "Specificity and denaturing of Small Business". International Small Business Journal, 23, 355-377.

Vinciane Servantie, "Les entreprises à internationalisation rapide et précoce : revue de littérature", Revue de l'Entrepreneuriat 2007/1 (Vol. 6), p. 1-28. DOI 10.3917/entre.061.0002

Wafi Chtourou, "Le développement international des P.M.E. Profils et défis informationnels", Gestion 2006/1 (Vol. 31), p. 88-97. DOI 10.3917/riges.311.0088

Wang, Y., 2016. "What are the biggest obstacles to growth of SMEs in developing countries? An emprical evidence from an enterprise survey". BorsaÍstanbul Review, 16(3), pp. 167176.

Ward, T. (2004), "Cognition, creativity, and entrepreneurship", Journal of Business Venturing, Vol. 19, pp. 173-88.

\section{Copyrights}

Copyright for this article is retained by the author(s), with first publication rights granted to the journal. This is an open-access article distributed under the terms and conditions of the Creative Commons Attribution license (http://creativecommons.org/licenses/by/4.0/) 